\title{
Héder Klára
}

\section{Az anticipált megfigyelés, mint az antikorrupciós eredményesség egyik gátja}

\section{Anticipated surveillance as one of the barriers to success in anti-corruption efforts}

\begin{abstract}
Absztrakt
A tanulmány a KÖFOP-2.2.3-VEKOP-16-2016-00001. projekt keretében kialakított, Integritás: szilárd erkölcsiség a gyakorlatban címü, 15 modulból álló e-learning tananyag kialakításának folyamatát mutatja be. Ismerteti a korrupcióval és az integritással kapcsolatos társadalmi, szervezeti, és pszichológiai (háttér)tényezők feltételezett oktatás-módszertani következményeit, külön hangsúlyt fektetve a résztvevők által feltételezett megfigyelés gátló hatásaira, illetve ezek kivédésére alkalmazott oktatás-módszertani megoldásokra.
\end{abstract}

Kulcsszavak: integritás, korrupció, SZEM-modell, anticipált megfigyelés, e-learning, tananyagfejlesztés

\section{Abstract}

The study is based on KÖFOP-2.2.3 - VEKOP-16-2016-00001 project and describes the process of developing an e-learning curriculum, ('Integrity: Solid Morals in Practice'), developed within the framework of the project. It introduces the assumed educational-methodological consequences of the social, organizational and psychological background factors in connection with corruption and integrity. It puts an emphasis on the inhibiting negative effects of the surveillance anticipated by the participants; and on the educational-methodological solutions applied to eliminate these effects.

Keywords: integrity, corruption, SZEM (Hung. abbr. for Indicator of Solid Morals) model, anticipated surveillance, e-learning, curriculum development 


\section{Bevezetés}

Jelen tanulmány az Integritás: szilárd erkölcsiség a gyakorlatban címü e-learning tananyag kialakításában szerepet játszó (projekt)elvárások, pszichológiai és oktatás-módszertani szempontok leírása után, bemutatja azokat a feltételezett tényezőket, félelmeket és prekoncepciókat, amelyeket a képzésben érintettek érezhetnek egy ilyen tananyag elvégzésekor. Megkísérli bemutatni azokat a fejlesztői módszereket, amelyek e hatások kivédésére, a projekt céljainak elérése érdekében, továbbá az érintettek integritásának erősítésére történtek.

\section{Integritás: társadalmi megközelítés és egyéni attitüd}

A korrupció ${ }^{1}$ kezelésével, megelőzésével kapcsolatos szemléletváltás hatására napjainkban a represszív megközelítést komplex értékalapú szemlélet váltotta fel; s a korábban szinte ismeretlen integritás fogalom mára valóban meghonosodott a közigazgatásban. (Pulay, 2014)

A korrupcióellenes politikák életciklusainak vizsgálatával (Báger et al., 2008; URL1) elmondható, hogy napjainkra Magyarországon is a több lépésböl álló fejlődési folyamat során a hangsúly a szük értelemben vett korrupciókezelésről az integritás tágabb fogalmára, társadalmi kontextusára és előmozdítására helyeződött át ${ }^{2}$. Hazánkban sokáig elsősorban a büntető jellegü, represszív szemlélet volt jellemző, bár a terület szakértői több ízben hangsúlyozták a prevenciós módszerek beemelésének fontosságát a probléma kezelésébe ${ }^{3}$.

Az összetett kormányzati stratégia és erőfeszítések hatására azonban mára jelentős változás történt a kérdéskör megközelítésében. Megkezdődött a szabálykövetés-központú szemlélet átalakulása, és megerősödni látszik az integritásalapú szemlélet, bár ennek ellenére az Állami Számvevőszék 2008. évi jelentésében (URL1) még az alábbiakat olvashatjuk:

1 Jelen írás célja és terjedelme nem teszi lehetővé a korrupció, illetve az integritás fogalmának, a kérdéskörben született elméletek könyvtárnyi irodalmának részletezését. Érdeklödők számára néhány korrupciós elméleti összefoglalás. (Réthy, 2016, Köhalmi 2015, Báger, 2016.) A szerző által a továbbiakban alkalmazott fogalmak Nemzeti Korrupcióellenes Program (2015) definícióhoz illeszkednek, melynek értelmében korrupciónak tekinthető a Büntető Törvénykönyvröl szóló 2012. évi C. tv. XXVII. fejezetén belüli tényállások és azokon túlmutató minden olyan társadalmi jelenség, amely során valaki a rábízott hatalommal magán- vagy csoportelőny érdekében visszaél. Alkalmazott integritás fogalom: sértetlenség feddhetetlenség, megvesztegethetetlenség, tisztaság állapota egyéni és szervezeti szinten.

2 Nemzeti Korrupcióellenes Program. (2015-2018); (URL2)

3 „A hazánkban jelenleg elötérben álló büntetö jellegü, repressziv szemlélet - fokozott mértékben indokolt - követése mellett szükséges és célszerü olyan stratégiát kialakitani, amelynek eredményeként a prevenció kerül elötérbe". (Báger, 2012)
„Az integritás egy teljesen más nézöpontot igényel ma Magyarországtól. Kicsit nehéz ezt a szemléletet megszokni, pedig sokkal elöremutatóbb, pozitívabb, mint a korrupció szankcionálása. Ugyanakkor ma Magyarországon a repressziót nem lehet háttérbe szoritani, erre még a továbbiakban is szükség van." (Báger, 2012) A fentiek alapján látszik, hogy a korrupció-ellenes politikák életciklusai közti (szemlélet)váltás korántsem lineáris. (Klotz, 2016) A sokszor szövevényes és összetett folyamat során mind társadalmi, mind pedig szervezeti szinten megfigyelhetők remissziók, regressziók, illetve kerülőutak a probléma kezelésében. Nem elhanyagolható az sem, hogy a különböző kultúrák, kulturális jegyek és hatások jelentősen befolyásolják a társadalmi folyamatok széles skáláját, így a korrupciókezeléssel kapcsolatos eredményességet is. (Réthy, 2016)

További nehézség, hogy a normaszocializációs folyamatok sem tekinthetők minden esetben problémamentes folyamatnak. (Pallai, 2012) Mindezen hatások mellett az ún. uralkodó szemlélet, és a tényleges, a kérdéskörben megjelenő egyéb - például társadalmi vagy szervezeti - hatások közti eltérések, az intézkedések és a gyakorlat közti diszkrepanciák is befolyásolhatják a kérdéskör megítélését; akár inhomogén véleményhálót hozva létre egy adott társadalmon belül is. Az értékek széttartó társadalmi kohabitációja mellett az érintett személyek korrupcióval, integritással, illetve a kormányzati intézkedésekkel kapcsolatban átélt személyes tapasztalatai, és attitüdjei is komoly diverzitási faktorként jelenhetnek meg a probléma leküzdésekor.

Ezek - és még sok más hatás - eredőjeként egy adott társadalomban, illetve szervezetrendszerben, szervezetben ezért egyidőben élnek/élhetnek együtt eltérő megközelítések, internalizációs szintek, intézkedések, szervezeti kultúra elemek, vagy éppen egyéni korrupcióval kapcsolatos attitűdök.

Ha pedig a fenti okfejtés helyes, akkor egy olyan korrupcióellenes tananyagnak, amely rendkívül sokféle szervezetben dolgozó, nagyszámú célcsoport számára készül, nemcsak az egy társadalmon belül élő eltérő nézetekkel, hanem a sokféle érintett különféle attitüdjeivel is meg kell hogy küzdjön ahhoz, hogy sikeres integritás-központú szemléletformálásra legyen képes.

E dolgozat az integtirás-központú képzési cél oktatás-módszertani megfontolásain keresztül elemzi, hogy:

- milyen tényezők játszhatnak gátló szerepet egy preventív szemléletü, integritás tematikájú, szemléletformáló e-learning tananyag elsajátításában;

- és milyen módszerekkel védhetők ki ezek a nem kívánt hatások,

- és tehető sikeressé a célzott szemléletformálás, a szilárd erkölcsiség támogatása. 


\section{Az e-tananyag szemlélete: \\ a korrupt viselkedés integratív megközelítése}

A korrupció, mint tanult, társas viselkedés

A korrupció megközelítésében és magyarázatában alapvetően három szemléletmód különíthető el. Az első magyarázatcsoport az egyéni tényezőkre helyezi a hangsúlyt az események alakulásában, míg a másik irányvonal inkább a társadalmi, makrostruktúrális tényezők ${ }^{4}$ felől közelíti meg a kérdést.

Harmadik magyarázóelv-csoportnak tekinthetjük az integratív megközelítést, amely az egyének társas környezetben mutatott viselkedéseként tekint a korrupt magatartásra, és társadalmi, valamint pszichológiai okok együttesével magyarázza a jelenséget.

A korrupcióval kapcsolatos cselekvési szándék kialakulásának magyarázatában a tervezett viselkedés elméletén (The Theory of Planned Behavior Ajzen, 2005) alapuló SZEM-modell (Hunyady, Münnich, 2015, 2016) (URL3) kialakítása jelenthet egyfajta fordulópontot. Az elmélet a korrupcióra hajlamosító tényezők vizsgálatáról a korrupciónak való ellenállás, az integritás és a szilárd erkölcsiséggel rendelkező személyek támogatására helyezte át a hangsúlyt. (Hunyady, Münnich 2015) (URL3) (Malét-Szabó, 2016) (Malét-Szabó 2018/a; Münnich, 2018)

A fenti szemléletnek - a kialakított e-tananyagnak, és a jelen tanulmánynak egyaránt - központi koncepciója az, hogy a korrupció tanult ${ }^{5}$, társas tevékenység, melyet egyének követnek el valamely szociális térben, társas, szervezeti(Pallai, 2010) (URL4) társadalmi- (Takács et al. 2011) államigazgatási hálózatban, kontrollkörnyezetben. (Pulay, 2014)

Ez a megközelítés a korrupciós eseményt szándékos, tudatos cselekménynek tartja:

- amelyben nem lehet észrevétlenül részt venni;

- amelyhez kialakult egyéni cselekvési szándék és átgondolás szükséges,

- s amelyet a környezet és az érintett személy jellemzői, pszichológiai tulajdonságai egyaránt befolyásolnak.

4 Jól áttekinthető összefoglalás a fontosabb makrostrukturális okokról. (Varga, 2017)

5 „A szilárd erkölcsiség egy tanult tulajdonságunk, amit a tágabb és szükebb környezetünktöl tanulunk meg, azokat egyénisegünknek megfeleloen atformáljuk, átszinezzük, és beépitjük személyiségünkbe, senki sem születik erkölcsösnek vagy erkölcstelennek.” (Hunyady, Münnich, 2015, 79.). (URL3)
A korrupció, mint módositható viselkedés

Ha a SZEM-modell kutatási eredményeinek hatására erősödik az a szemlélet, amely a korrupt viselkedést tanult, s így megváltoztatható cselekvésnek tekinti, akkor elkerülhetőbbé válik az érintettek tartós stigmatizálása (pl.: korrupt személyiség) és ezáltal pedig jobban megnyílik az út a kérdéskörben érintettek más szempontú megközelítése - pl. szemléletformálás, képzés, a szilárd erkölcsiség támogatása - irányába is.

„Amennyiben ez elfogadható feltevés, akkor van esélyünk megfelelö képzéssel, szabályozással, erkölcsi példamutatással befolyásolni annak ${ }^{6}$ személyenkénti alakulását, és ezáltal csökkenteni a kétségtelenül meglévö egyéb negativ irányú hatásokat (pl. rossz családi-baráti környezet, nehéz anyagi helyzet, stb." (Hunyady, Münnich, 2015, 5.)

A SZEM-modell által nyújtott szemléletváltás ezért a preventív, integritás-központú, a szemléletformálás irányába elmozduló további új módszerek, képzési lehetőségek felé is utat nyithat.

\section{Képzési alapadatok és problémák}

\section{E-tananyag: képzési elvárások, célok}

Az e-learning tananyag a KÖFOP-2.2.3-VEKOP-16-2016-00001. számú Kapacitásfejlesztés és szemléletformálás a korrupciós esetek nagyobb arányú felderítése illetve megelőzése érdekében címü kiemelt projekt a Belügyminisztérium oldali feladatainak részeként - a Nemzeti Védelmi Szolgálattal, mint a projekt vezetőjével együttműködve - került kidolgozásra.

A projekt keretében 2018-ban megkezdődött a hivatásos állomány képzése a képzők és a közremüködők (humán vezetők, oktatási szakemberek, továbbképzési kapcsolattartók, trénerek) felkészítésével, illetve novemberben elindult a célcsoportok oktatása is. Az e-tananyag a teljes hivatásos állomány számára kötelező továbbképzési programként került meghirdetésre.

Az e-learning tananyaggal szemben megfogalmazott elsődleges cél az volt, hogy a projekt keretében lezajlott, a SZEM-modell rendvédelem-specifikus jellemzőit feltáró tudományos kutatás eredményeire épülve, elsősorban nem kognitív fókuszú, ismeretközlő szakanyag, hanem

6 A szilárd erkölcsiségnek, a korrupciónak való ellenállás képességének. (kiegészités: szerző) 
- szemléletformáló,

- a korrupció, a szilárd erkölcsiség és az integritás kérdését új szempontból megragadó,

- szemléletes képzési anyag készüljön el.

Képzési célcsoport és képzési szakanyag

A tervezett képzés a teljes hivatásos rendvédelmi állomány, közel 60 ezer fö számára készült, mint kötelező központi továbbképzési program. Ilyen nagy létszámú, eltérő számítástechnikai kompetenciával, iskolázottsággal, szakmai tapasztattal és ismerettel rendelkező inhomogén csoport számára egységes és ugyanakkor hasznos képzési anyag készítése komoly kihívás.

Ahogy a bevezetőben is olvasható, egy olyan korrupcióellenes tananyagnak, amely a rendvédelmi hivatásos állomány teljes spektrumát felölelő ${ }^{7}$, rendkívül sokféle szervezetben dolgozó, nagyszámú célcsoport számára készül,

- nemcsak az egy társadalmon belül élő eltérő aktuális nézetekkel,

- szervezeti különbségekkel,

- hanem a sokféle érintett egyén különféle attitüdjeivel is számolnia kell ahhoz, hogy sikeres integritás-központú szemléletformálásra legyen képes.

A nagyszámú eltérési lehetőség miatt továbbá a tananyag szerzője nem feltételezhetett olyan alapismereteket, pszichológiai háttértudást, amellyel a résztvevők mindegyike rendelkezik, s amelyre a képzés során részletes magyarázat nélkül építeni lehet.

Nem könnyíti meg a feladatot az sem, hogy az e-learning forgatókönyv alapjául szolgáló, a SZEM-modell rendvédelemspecifikus jellemzőit feltáró tudományos kutatás eredményei alapján készített oktatási segédanyag ${ }^{8}$, igen nagy terjedelmü (188 oldal), akadémiai nyelvezetü, komplex pszichológiai háttérismereteket megkívánó tudományos szakanyag, mely korántsem tekinthető könnyen feldolgozandó alapanyagnak a témában járatlan résztvevő számára.

A tananyag elkészítésének alapjául szolgáló tudományos kutatás eredményeként összeállított oktatási segédanyag rendkívül sok értékes információt ad a téma iránt érdeklődők számára, de éppen komplexitása, strukturális meg

7 A négy rendvédelmi terület, melynek hivatásos állományát a tananyag elérni kívánja: a rendőrség, a katasztrófa-védelem, a büntetés-végrehajtás, és a polgári titkosszolgalatok

8 A KÖFOP-2.2.3-VEKOP-16-2016-00001. szämú „Kapacitásfejlesztés és szemléletformálás a korrupciós esetek nagyobb arányú felderitése illetve megelözése érdekében " címú kiemelt projekt anyagai között fellelhetó belsoo szakanyag. A tudomannyos eredmények várható megjelenése tanulmánykötet formájában várható a BM kiadásában, 2020-ban. közelítése és absztrakt jellege miatt kevéssé tünhet életszerünek vagy éppen szemléletformálónak egy terepen dolgozó gyakorlati szakember számára.

Adott volt tehát a kérdés: Hogyan lehet egy ilyen nagy létszámú, jelentősen inhomogén célcsoport számára úgy feldolgozni a szakanyagot, hogy a tudományos tartalmat megtartva valóban szemléletformáló képzéssé váljon?

Képzési koncepció: személyes érintettség érzése, és életszerü példák

A fenti kérdés esetén az e-tananyag forgatókönyvírója (a jelen írás szerzője) a hagyományos, elsősorban ismeretátadásra épülő oktatási szemlélettől eltérő megközelítést tartotta hatékonynak ${ }^{9}$, s alkalmazta - a megrendelő előzetes jóváhagyásával és döntése alapján - a tananyag kialakításában.

E megközelítés szerint a személyes érintettség érzésének fokozásával, a gyakorlathoz köthető, életszerü példák alkalmazásával közelebbé tehető a résztvevők számára az elméleti szakanyag és hatékonyabban átadható a tananyag központi üzenete:

A korrupt viselkedés bonyolult társas térben zajló, egyéni döntésekre épülö, tudatos viselkedés. Ha megismerjük ezeket a hatásokat és felismerjük a veszélyeztetö tényezöket könnyebb helyesen dönteni, etikusan eljárni; vezetöként prevenciós elemeket alkalmazni, ellenlépéseket tenni; az integritás követelményeinek eleget tenni egyéni és szervezeti szinten egyaránt. ${ }^{\mathbf{1 0}}$

A személyes érintettség fokozása és a célcsoport tagjai számára életszerü példák alkalmazása, mint választott oktatás-módszertani metódus azonban komplex problémák sorát is magával hozhatja.

A legfontosabb megállapítás az, hogy a korrupció kényes téma. Az egyéni tapasztalatok alapján érzelmek széles skáláját mobilizálhatja a lebukástól való félelemtől kezdve a korrupt kolléga iránt érzett haragig.

Az érzelem pedig lényegi befolyást gyakorol a kognitív múködés minden területére, beleértve az emlékezetet, a figyelmet, a döntéshozatalt, a deklaratív tudás szabályozását és nemcsak befolyásolja, hanem szabályozza is az információfeldolgozás folyamatát. (Adolphs-Damasio, 2003)

Ezért minél személyközelibbé teszünk egy tananyagot, minél életszerübbek a példák, annál nagyobb teret kapnak a résztvevők emocionális jellemzői, amelyek segíthetik is a tananyag céljának elérését, az (integritással kapcsolatos) szemléletformálást, de gátló hatást is gyakorolhatnak, ha a mobilizált destruktív érzelmek gátolják a szükséges információfeldolgozást.

\footnotetext{
9 A képzés lezárult, az elégedettség-mérési eredmények feldolgozása folyamatban van.
} 10 A szerző összefoglaló megfogalmazása a tananyag fö üzenetéról. 
Nagyon fontos tehát számot vetni azzal, hogy milyen emocionális hatások, attitüdök játszhatnak szerepet a tananyag elsajátításakor. Milyen tényezők vethetik vissza a sikert?

\section{A képzési eredményességet befolyásoló tényezők}

A korrupció-ellenes politikák életciklusainak hatása az egyéni attitüdökre

Mivel a korrupciós cselekmények csak társas/társadalmi környezetben, szabályhálóban, több személyt érintve követhetők csak el, a kérdéskörben uralkodó társadalmi megközelítés, korrupció-ellenes politika nagy hatással van arra, hogy milyen egyéni értékrend, attitüd alakul ki a társadalom tagjaiban, az érintettekben, a közszolgálat munkatársaiban.

A korrupció-ellenes politikák elemzése alapján hat föbb szakasz különíthető el. (Báger et al. 2008, 17-18.)

1. A korrupció figyelmen kívül hagyása/visszautasítása (a korrupció kérdésköre tabu, nem tárgyalható);

2. Tudatosulás/Ébresztő (valamely helyzet, incidens miatt a korrupció, mint probléma nyilvánvalóvá válik);

3. Keményvonalas vagy szabálykövetés központú szemlélet (központban a (büntető) jog, a jogszabályok és a korrupció elfojtása);

4. A kizárólag elfojtáson alapuló megközelítés korlátainak felismerése (annak felismerése, hogy a represszión alapuló módszerek nem bizonyulnak elég hatékonynak);

5. Középpontban a megelözés/integritás alapú szemlélet (szemléletváltás, integritáspolitikai intézkedések, fókuszban a megelőzés);

6. Kiegyensúlyozott megközelítés: megelőzés/elfojtás (a korrupciós jelenségeket és magatartást megelőző és elfojtó elemeket egyaránt tartalmazó, kiegyensúlyozott megközelítés).

A különféle korrupció-ellenes politikák szakaszainak társadalmi átmenete nem tekinthető lineáris folyamatnak. Ennek okai számosak: egyfelől, bár a probléma szinte mindenhol megjelenik, maga a korrupció eltérő mértékü lehet a különféle országokban, illetve a kialakult szabályozás sem egységes, még akár csak az Európai Uniót tekintve sem. ${ }^{11}$

11 „A korrupció - bár jellege és mértéke különbözhet - valamennyi uniós tagállamot és az Unió egészét is kárositja... , Ugyanakkor a korrupcióellenes jogi keret végrehajtása a különbözö uniós tagállamokban továbbra sem egyenletes, és összességében véve nem kielégitö. Az EU korrupcióellenes jogszabályait nem ültette át valamennyi tagállam.,, (URL6)
Bár az országok közötti különbségek igazán jelentősek lehetnek, nem elhanyagolhatóak az egy országon, egy társadalmon belül egyidőben megfigyelhető különféle szemléletek együttélései sem. Egy adott ország különféle területein, eltérő szervezeti kultúrájú szerveknél jelentős különbség lehet abban, hogy a korrupcióval, vagy az integritással kapcsolatos kérdéseket hogyan közelítik meg. Az egyén korrupcióval kapcsolatos attitüdjének kialakulásában pedig mindezek a szempontok jelentősen megjelennek: vagyis, hogy valaki mely országban, milyen régióban él, mely szervezethez tartozónak érzi magát, milyen eddigi (társadalmi) tapasztalatai vannak, milyennek érzi a korrupcióval kapcsolatos uralkodó megközelítést, és milyen személyes élményeket élt meg ezzel kapcsolatban. Mivel Magyarországon nagyon sokáig inkább a represszív szemlélet élvezett elsőbbséget, feltételezhető, hogy e szemléletmód jelentősebb ismertséggel rendelkezik az érintettek körében, mint a preventív, integritás-központú megközelítés, s így több személyes tapasztalat is kapcsolódik hozzá. Ennek következtében a represszióhoz kapcsolódó személyes tapasztalatok, attitüdök feltételezhetően mélyebben beágyazottak, érzelmileg telítettebbek és könnyebben elöhívhatóak: összességében erősebb attitüdkomponensekkel rendelkeznek, nagyobb érzelmeket involválnak és kézzelfoghatóbbnak tünnek.

\section{Szervezeti korrupció-ellenes politika és egyéni attitüdök}

A társadalmi hatások mellett a szervezeti jellemzők is befolyásolják a kialakult egyéni attitüdöket. Bizonyos szervezeteknél -mint amilyenek például a rendvédelmi szervezetek is -tovább fennmaradhat a tiltáson, represszív szemléleten alapuló erős korrupcióellenesség, és kisebb szerepet kap(hat), vagy éppen nehezebben honosodik meg a preventív, integritás-központú megközelítés. (URL7)

Ennek legfontosabb oka talán az, hogy a tisztességtelen, korrupt viselkedés olyan mértékben ellentétes azzal a társadalmi céllal, amellyel ezek a szervezetek létrejöttek, hogy mind szervezeti, mind egyéni szinten is az elutasító szemlélet komoly dominanciára tehet szert körükben. ${ }^{12}$

A rendvédelmi szervek jellegükből adódóan sem türhetik a soraikban megjelenő korrupt magatartást, $\mathrm{s}$ az ilyen viselkedést tanúsító személyek komoly retorziókra számíthatnak. Így ezeknél a szervezeteknél a kérdéskör szervezeti és egyéni megközelítésében akkor is kiemelt szerepet kaphat a keményvonalas vagy szabálykövetés központú szemlélet néven jelzett korrupcióellenes politika,

12 A korrupció alattomos és romboló, a kiépített rendỏri közbizalomra, és a teljes rendőr-szakma megbecsülésére jelentős negatív hatást gyakorló jellegét emeli ki Finszter Géza (2000) is a fogalom meghatározásában. 
hogyha társadalmi, politikai szinten már inkább a megelőzés/integritás alapú szemlélet, vagy éppen a kiegyensúlyozott megközelítés az uralkodó.

Röviden szólva: a hivatásos állományban a korrupció -lopás/csalás/tisztességtelenség -büntetés fogalmi térkép/szemantikus háló nagyon erősen megjelenhet ${ }^{13}$ mind a szervezeti, mind pedig az egyéni megközelítésben, attitüdben.

Ha pedig az előző következtetés helyes, akkor a hivatásos állomány tagjai maguk is többségében inkább a represszív szemléletet követik. Másoknál-és akár önmaguknál is - mélyen elítélik azokat az elemeket, amelyröl úgy gondolják, hogy jellemzőek a korrupt viselkedést mutatókra ${ }^{14}$.

A fentiek alapján az e-learninget elvégző személyek kapcsán az alábbiak feltételezhetők:

- minden módon kerülik, hogy magukat korrupt viselkedést mutató személyként jelenítsék meg, még lényegtelen kérdésekben is;

- várhatóan nem adnak korrupciós hatásokra, korrupciós szándékra utaló válaszokat semmilyen feladathelyzetben, még akkor sem, hogyha az segítené a tananyag megértését;

- résztvevők véleményük önkéntes cenzúrázásával kívánnak önmaguk és a képzést biztosító felettes szerv felé egyaránt kedvezőbb színben feltűnni, ezáltal pedig a lehetséges retorziókat elkerülni.

Ha azonban egy életszerü példa feldolgozásakor a résztvevők várhatóan mindig tökéletesen viselkednek, semmilyen - esetleg meglévő -kételyüknek nem adnak hangot, a társas kívánatosság szerint feltételezett, elvárt helyes választól semmilyen módon nem kívánnak eltérni, akkor a tananyagban nagyon nehezen lehet tanulói aktivitással bemutatni a kérdéskör árnyalt értelmezésének finomságait, különböző nehézségeit, problémáit. Az (önkéntesen) cenzúrázott válaszok ugyanis nem teszik lehetővé a helyzet cselekvő átélésével történő felismerését, a felmerülő problémák mélyebb megértését; a várható szépített válaszok pedig lényegében a képzés céljait teszik elérhetetlenné.

\section{Az anticipált megfigyelés, mint képzésbefolyásoló tényezó}

A fentieken túl problémaként jelenik meg, hogy a képzési célnak jobban megfelelő, személyesebb, a korrupcióval kapcsolatos egyéni véleményekre is rá-

13 A fenti állitás a szerző feltételezése, kutatási alátámasztás nélkül. (A taxonómikus szerveződés, szemantikus haló pszichológiai jellemzoirồ. (Csepe et al. 2007, 187-189.)

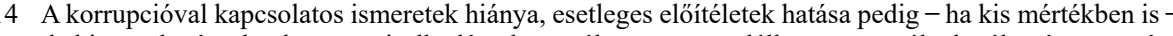
de kimutatható volt a korrupt viselkedéssel személyesen nem találkozott személyek véleménye esetén. (Münnich, 2018), így a személyes előfeltevések a tananyaggal kapcsolatban is játszhatnak valamilyen szerepet. kérdező tananyag mobilizálhatja az egyén korrupcióval szembeni, a repressszív megközelítésből származó tapasztalatait, félelmeit.

A szakanyag feltételezhetően a korrupcióellenesség személyes attitüdmintázati komponenseit is aktiválja, s azt a félelmet hozhatja elő a megszólítottakból, hogy a képzés valójában csak egy legenda, amely mögött valójában az egyénekre vonatkozó adatgyüjtés áll15: ki mennyire korrupt, ki mutat olyan (elő) jeleket, amely korrupciós veszélyeztetettségre/fertőzöttségre utalhat. Vagyis a képzési anyagban azért szerepelnek életszerü példák, hogy a résztvevők hitelesebb választ adjanak, $\mathrm{s}$ mindez előkészítsen egy beavatkozást: az állomány -rejtett -korrupcióval kapcsolatos attitüdjeinek felmérése után meg lehessen tenni a megfelelő lépéseket (értsd: a korrupció szempontjából veszélyeztetett személyek kiszürését).

A fejlesztőnek tehát számolnia kellett azzal a mélyen gyökerező résztvevői félelemmel is, hogy a tananyag valójában egy represszív központi intézkedéscsomag része, amelynek a célja a korrupt személyek kiszürése és megbüntetése. A fenti hatások eredőjeként a képzés kialakításakor ezért fontos volt az integritás-központú preventív szemlélet, az életszerüség, és személyes érintettség fenntartása, azonban nagyon fontos az is, hogy ki tudjuk küszöbölni a pozitív énbemutatás, társas kívánatosságnak megfelelő szépített válaszok adása irányába történő szociális nyomás hatását.

Ezért a tananyag elkészítésekor az életszerü, de mégsem túl erős, vagy negatív érzelmeket involváló példák árnyalt, aktivitásközpontú, szituatív feldolgozása (helyzetszimuláció) látszott megfelelőnek, ahol a válaszlehetőségek közül nem volt nyilvánvaló, hogy melyik az elvárt.

\section{Egyéni tényezök hatása szimulált korrupciós helyzetben}

Egy korrupciós helyzet szimulációja életszerübbé és átélhetőbbé teszi a problémát, azonban hasonló problémákat is okozhat, mint egy valós helyzet, hiszen - a kialakuló cselekvési szándékot sok tényező befolyásolja,

- $\quad \mathrm{s}$ a cselekvési szándék megjelenése nem feltétlenül vezet magához a cselekvés kivitelezéséhez is.

Hogyan hívható akkor elö a képzésben résztvevő valós viselkedési szándéka egy korrupciós szimulációs helyzetben?

15 A feltevés első pillantásra talán túlzónak tủnhet, azonban hogy a célcsoport számára mennyire valós lehetöséget képvisel, arra példa, hogy a szerző személy szerint több ízben maga is kapott erre vonatkozó konkrét kérdéseket az e-tananyaggal kapcsolatban a hivatásos állomány tagjaitól a fejlesztés szakaszá- 
A korrupció szempontjából fontos emberi tényezők/jellemzők (Münnich, 2015) az egyén személyiségjellemzői, az egyénnek a cselekedettel kapcsolatba hozható attitüd-rendszere, az egyénnek a közösségcselekedet relációban való percepciói, és az egyénnek a cselekedetre vonatkozó percepciói.

A SZEM-modell (Hunyady, Münnich, 2015, 2016) e tényezők szerepét is vizsgálja a korrupcióval kapcsolatos viselkedési szándék kialakulásában.

A modell az Ajzen-féle tervezett viselkedés elméletéböl indul ki, amely az erkölcsileg helyes és kifogásolható cselekedetek és az azt megelőző cselekvési szándék kialakulására ható három fontos tényezőt-attitüdbeli tényezők, társas környezeti normatényezők és a cselekvés kivitelezése felett érzett személyes kontroll - különít el, és a modell ezt bővíti további kiegészítő hatótényezőkkel. (ld. 1. számú ábra)

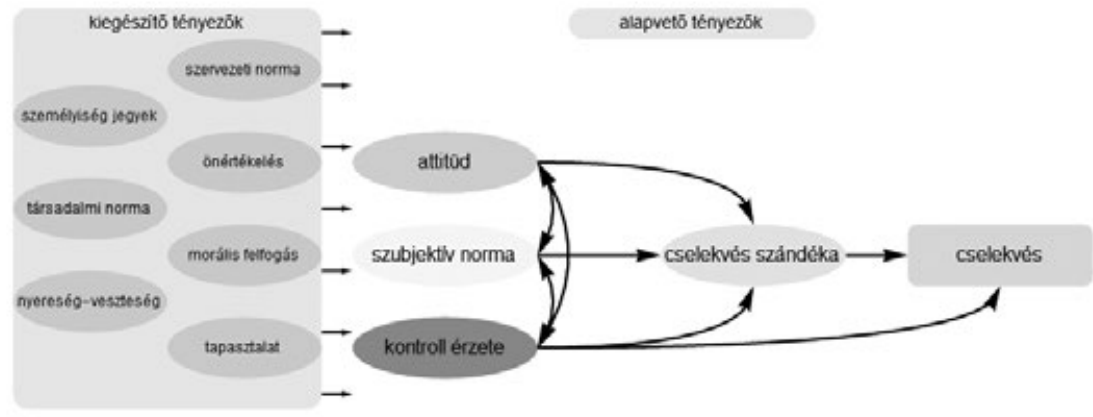

1. számú ábra: SZEM-modell (Hunyady, Münnich, 2015, 79.)

E tényezők azonban nem csak a korrupt viselkedéssel kapcsolatos szándék kialakulásában, és a korrupt viselkedés kivitelezésében játszanak szerepet, hanem arra is hatással lehetnek, hogy egy korrupciós helyzet szimulációjában milyen viselkedést mutatnak az érintettek.

\section{Hogy miért érdekes mindez?}

Mivel a képzés célja a szemléletformálás volt, olyan alappélda kiválasztására volt szükség, mely a nagy létszámú résztvevők többségének, vagy éppen mindegyikének érthető, szemléletes, de nem involvál olyan erős érzelmeket, személyes tapasztalatokat, vagy kontrollérzet-hiányt, amelyek csökkenthetik az őszinte válaszadásra vonatkozó cselekvési szándék kialakulását, és annak megjelenési valószínüségét.

A fentiek fényében a választás végül egy gépkocsi vásárlás során történő illegális adatkérésre esett. A kiválasztott példa reményeink szerint
- kellően hétköznapi ahhoz, hogy szemléletes legyen bármely rendvédelmi szervtől érkező résztvevő számára,

- ugyanakkor nem annyira szakmai, hogy felmerüljön az adott személyre vonatkozó szakmai adatgyüjtés veszélye;

- s elég könnyen érthető és kezelhető, hogy valóban megjelenjen a válaszadásra vonatkozó cselekvési szándék.

A fejlesztő az óvatos példaválasztás mellett gamifikációs eszköztár alkalmazásával és a tananyagrendszer felépítésének célzott megválasztásával is törekedett a fenti problémák orvoslására, a képzés hatékonyságát gátló társadalmi, szervezeti és egyéni tényezők hatásának minimalizálására.

\section{Integritás: szilárd erkölcsiség a gyakorlatban: a tananyag megvalósítása}

\section{Tananyagszerkezet}

A képzés céljaihoz illeszkedve szükség volt az elméleti ismeretek átadására, többféle szakterületi helyzet bemutatására, a korrupciós helyzet felismerését, elkerülését vagy éppen az ellenlépések megtételét szolgáló képzési szakaszra, és egy, csak a vezetők számára kialakított tananyagrész elkészítésére is. Ennek érdekében végül a 2. számú ábrán látható képzési struktúra került kialakításra ${ }^{16}$.

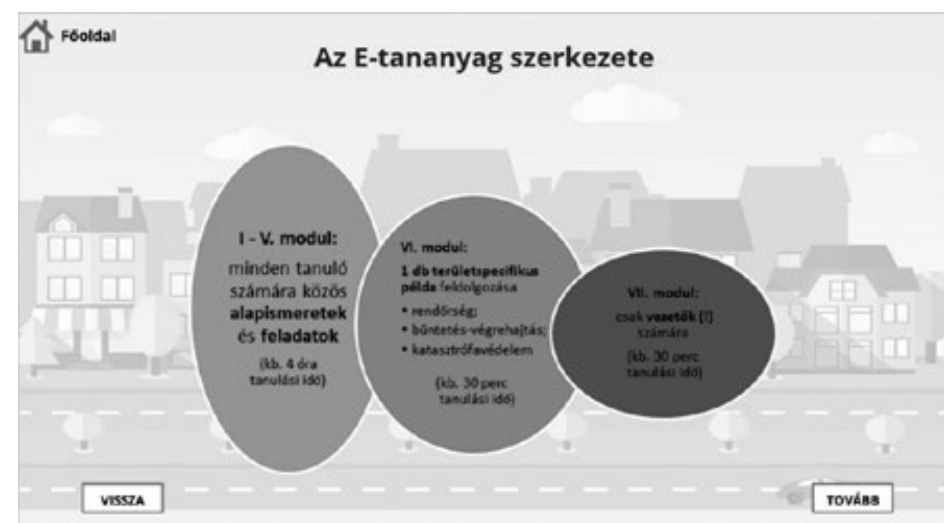

2. számú. ábra: az Integritás: szilárd erkölcsiség a gyakorlatban címü képzés szerkezete (képzési képernyökép ${ }^{17}$ )

16 A tananyag a jogosultsággal rendelkező érintettek számára a tovabbkepzes.bmkszf.hu oldalon érhető el. 17 A tananyagképek készitöje a HRK Consulting Kft., a tananyag jogtulajdonosa a Belügyminisztérium. 


\section{Gamifikáció}

Az elkészült képzés céljai között szerepelt, hogy a 21. század digitális átalakulásához, az Y és Z generáció informatikai- és élettapasztalatához jobban illeszkedő feldolgozási móddal segítse a tananyag alapjául szolgáló tudományos kutatási eredmények megértését. Cél volt, hogy az e-tananyag ne csak száraz kognitív tényeket, fogalmakat és definíciókat közvetítsen, hanem az egyének kognitív sémáihoz, gyakorlati tapasztalataihoz jól illeszthető, személetes és életszerü módon járuljon hozzá az etikus, a szilárd erkölcsiségnek és az integritás követelményeinek egyéni és szervezeti szinten egyaránt megfelelö viselkedéshez. Ennek a célnak az eléréséhez a gamifikációs technikák alkalmazása tűnt a leghatékonyabbnak a képzés kialakításakor. Ezért a résztvevő a köszöntés után egy központi ,,játékfelületen” találja magát, ahova az egyes modulok elvégzése után mindig visszatér (ld. 3. számú ábra), s így követni tudja haladását az úton ${ }^{\mathbf{1 8}}$.

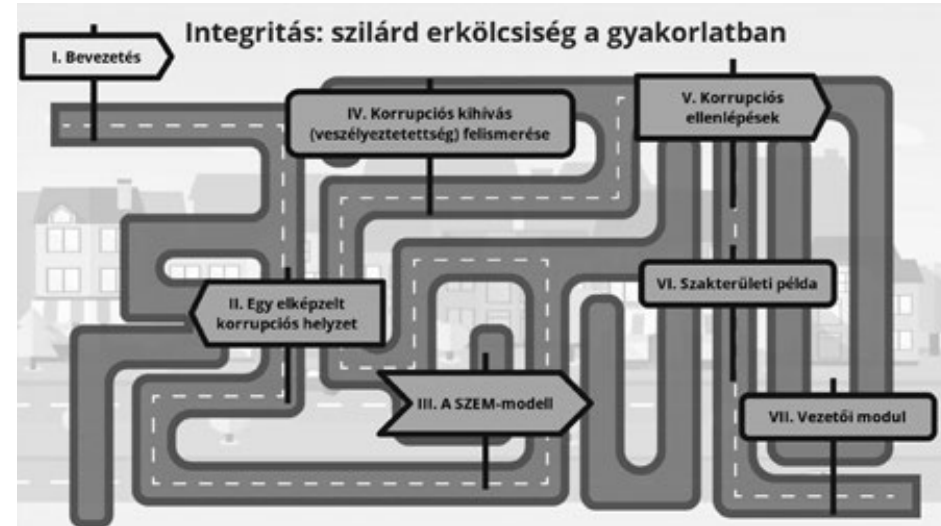

3. számú. ábra: az „Integritás: szilárd erkölcsiség a gyakorlatban” címü képzés központi oldal (képernyőkép, hivatkozás ld. 18. lábjegyzet)

A résztvevő nem az elméleti szakanyag logikáját követve ismeri meg a SZEM-modell alapján a korrupt viselkedés szándékát befolyásoló tényezőket, hanem egy életszerü korrupciós helyzet szimulációjában kell eljárnia egy általa választott férfi vagy női karakter nevében ${ }^{19} \mathrm{~s}$ csak ezt követően, saját válaszaihoz kapcso-

18 Az útra, mint központi képre azért is esett a választás, mert egyfelöl illeszkedik a közlekedési alappéldăhoz, masfelol vizualisan tükrozi a kerdeskor bonyolultsagat, és azt, hogy ennek ellenére elérhetỏ a kitüzött integritási cél egyêni és szervezeti szinten egyarán

19 A karakter lehett férfi vagy nö, sajăt vảlasztott névvel, és négy rendvédelmi szakterületről érkezhetett: rendőrség, büntetés-végrehajtás, katasztrófavédelem és polgári titkosszolgálatok. A résztvevő a továbbiakban ennek a választott karakternek a nevében oldja meg a feladatokat. lódva, mintegy magyarázatként ismeri meg az elméleti szakanyagot ${ }^{20}$ és halad végig újból a folyamaton és csökkenti az alappéldához kapcsolódó korrupció valószínüségét. (URL8)

A tananyag további szakaszaiban gyakorlati, a VI. modul esetében területspecifikus, a VII. modul esetében pedig vezetőknek készült példákon keresztül ismeri meg a résztvevő a korrupciós veszélyeztetettség felismerésével és a lehetséges ellenlépésekkel kapcsolatos tudnivalókat és gyakorlati tanácsokat.

A tananyag elején történő karakterválasztás (ld. 4. számú ábra)

- egyfelől gamifikációs elemként játékosabbá teszi a szükséges ismeretek elsajátítását,

- másfelöl távolításként, s így védelemként hat, a kapcsolati térben az egyénre nehezedő adatgyüjtési félelmeknél ${ }^{21}$, hiszen

Pl.: „Ha a választott karakterem férfi, pedig én nö vagyok, más neve van, és más területről is érkezett, mint én, akkor az ,,általa” megjelölt vélemények látszólag nem azonosak az én véleményemmel, ezért rólam ez alapján adat nem gyüjthetö, ellenem eljárni a korrupcióval kapcsolatos attitüdöm miatt nem lehet. ${ }^{22}$,

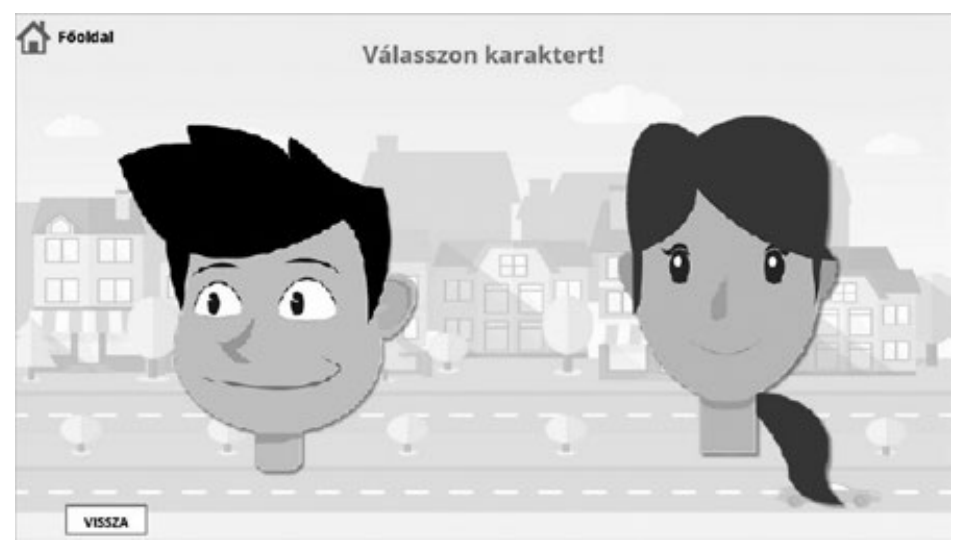

4. számú. ábra: „Integritás: szilárd erkölcsiség a gyakorlatban” című képzés: karakterválasztás (képernyőkép, hivatkozás ld. 18. lábjegyzet)

20 A képzés során egyébként a teljes szakanyag végig elérhető egy linken a téma iránt mélyebben érdeklödők számára.

21 Egy pszichologiai vizsgálat, vagy terápia esetén a távolitas nyujtotta lehetőséggel gyakran élnek olyan esetben, amikor a személyes bevonódâs érzelmileg tûlterhelheti az érintettet, vagy gatolja a valós válaszok megjelenését. Ilyen pl. a foleg gyermekek esetében alkalmazott „Világjatek", vagy a bábok segítségével tortenó traumafeltárás.

22 A szerző által írt lehetséges, elképzelt belső résztvevői monológ. Nem szószerinti idézet. 
A résztvevő a játékkarakter okozta érzelmi távolítás miatt feltételezhetően nem érzi olyan erősen annak a szükségét, hogy magát védve kitalálja, hogy melyik a jó válasz, s emiatt valóban át tudja gondolni, hogy az adott korrupcióveszélyes helyzetben mit gondolna, mit tenne, és milyen egyéb tényezők (ld. 5 számú ábra) befolyásolnák döntését. A fiktív karakterrel történő azonosulás így lehetőséget ad hitelesebb válaszok megjelenítésére, a felmerülő problémák mélyebb átgondolására, és az integritás követelményeinek jobban megfelelö szemlélet és cselekvési mintázat kialakítására.

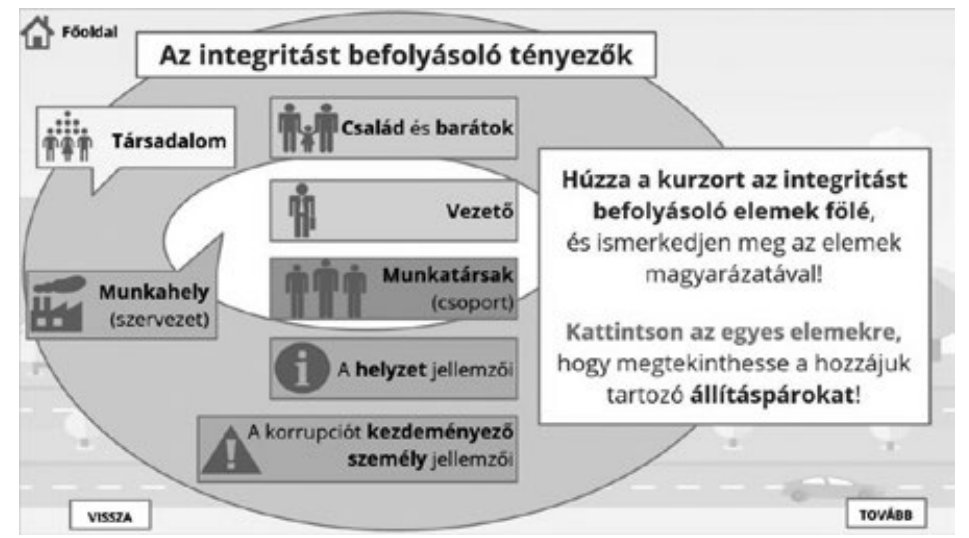

5. számú. ábra: Az integritást befolyásoló tényezők (képernyőkép, hivatkozás ld. 18. lábjegyzet)

A játékkarakter kiválasztása után a tananyagban az egyéni és a társas befolyásoló tényezők (pl. szervezet, család, vezető, barátok) jellemzőinek beállítása is állításpárok közül történő választással történik. Az állítások egyike inkább a korrupt viselkedés irányába mutat, míg a másik integritást támogató szemléletet tükröz. Az állítások pozitív megfogalmazása szándékosan nehezíti, hogy könnyü legyen kiszúrni a társadalmilag kívánatos választ (Pl. Az embereknek az a legfontosabb, hogy el legyen intézve. Lehetőleg gyorsan. vs. A többség úgy gondolja, hogy a törvényes rend a legfontosabb, és a szabályokat be kell tartani.). A résztvevő a föszereplő karakter és környezete jellemzése után megnézheti, hogy ezekkel a beállított feltételekkel a karakter milyen valószínűséggel követne el korrupt viselkedést.

A tananyag következő szakaszában az előző folyamatot ismétli meg a tanuló, azzal a különbséggel, hogy

- ezúttal az a feladata, hogy csökkentse az eredeti korrupciós valószínüség mértékét, és
- a - most már - megjelenő elméleti ismeretek és magyarázatok fényében válassza az integritást támogató állításokat.

A tananyag további szakaszaiban gyakorlati és területspecifikus példák segítségével ismeri meg a korrupcióveszélyes helyzetek felismerését és elkerülését szolgáló módszereket, ellenlépéseket; vezetők esetén pedig vezetői lehetőségeket. A tananyagfejlesztők szándéka szerint a tananyagba beépített gamifikációs elemek, a multimodalitásra ${ }^{23}$ és aktivitásra épülö feladatstruktúra, a kvíz-learning ${ }^{24}$ módszereit alkalmazó ismeretmegszilárdítás a téma mélyebb feldolgozására, emocionális lehorgonyzására, és adaptívabb gyakorlati alkalmazására ad lehetőséget.

A tananyagfejlesztéskor a képzési célok elérését gátló tényezők figyelembevételével törekedtünk a legfontosabb szempont megvalósítására: a szilárd erkölcsiség, az etikus viselkedés, az egyéni és szervezeti integritás megszilárdítására; olyan szemlélet kialakítására, amely alapján a rendvédelmi szervek munkatársai jobban felismerik, megértik és sikeresebben elkerülik a korrupció-veszélyeztetett helyzeteket.

\section{Összefoglalás}

A tanulmány bemutatta a KÖFOP-2.2.3-VEKOP-16-2016-00001. azonosítószámú, Kapacitásfejlesztés és szemléletformálás a korrupciós esetek nagyobb arányú felderítése, illetve megelözése érdekében címü projekt Belügyminisztérium oldali feladatainak részeként elkészült „Integritás: szilárd erkölcsiség a gyakorlatban" című e-tananyag kialakításában szerepet játszó, a szemléletformálást, mint kitüzött cél elérését támogató elméleti megfontolásokat, a mindezzel kapcsolatban feltételezhetően felmerülő nehézségeket, valamint a mindezek kezelésére alkalmazott megoldási módokat.

Kitért arra, hogy a társadalmi, szervezeti és egyéni attitűdök, nézetek és félelmek hogyan befolyásolhatják a képzés céljának elérését, az etikus, a szilárd erkölcsiségnek megfelelő viselkedéssel kapcsolatos szemléletformálást.

Bemutatta azokat az oktatástechnikai, képzésfejlesztési szempontokat és módszereket, amelyet a fejlesztők alkalmaztak a képzés kialakításakor -reményeik szerint sikeresen -a köz szolgálatában álló rendvédelmi hivatásos állomány egyéni és szervezeti integritásának támogatása érdekében.

23 A tananyag törekszik sok érzék megszólitására a tanultak mélyebb bevésése érdekében, ezért egyszerre ad vizuális, és auditív (pl. felolvasott szöveg) visszajelzést; procedurális aktivitást igénylö feladatstruktúrát.

24 Elsősorban kérdés-válasz módszertanra épülö, sok fejtörőt, versenyt, mérést, tanulói aktivitást ösztönző kérdést tartalmazó oktatási forma. 


\section{Felhasznált irodalom}

Adolphs, R. - Damasio, A., R. (2003) : Az érzelem és gondolkodás kölcsönhatása: egy neurobiológiai elképzelés. In: Forgács József (szerk.): Az érzelmek pszichológiája. Budapest: Kairosz Kiadó, 31-53.

Báger G. (2012): Korrupció,büntetés, integritás, kompetencia. Budapest: Akadémiai Kiadó

Benkő J., Klotz P., Lóczy P., Nagy M. (2016): Államigazgatási munkakörök korrupciós kockázatának elsődleges és másodlagos elemzése (KÖFOP-2.2.3-VEKOP-16. „Kapacitásfejlesztés a korrupciós esetek nagyobb arányú felderítése, illetve megelőzés érdekében” c. projektben); nem publikus dokumentum;

Csépe V., Győri M., Ragó A. (2007): Általános pszichológia 1-3. - 2. Tanulás - emlékezés - tudás. Budapest: Osiris Kiadó

Finszter G. (2000): Módszertani szempontok a rendőrségi korrupció kutatásához. Belügyi Szemle, 11, 3-32.

Hunyady Gy., Münnich Á. (2016): A szilárd erkölcsiség elvárása a rendvédelemben: egy lehetséges pszichológiai modell. Belügyi Szemle, 6, 34-68.

Klotz P. (2017): Az integritás-szemlélet lehetöségei a korrupció elleni fellépésben, különös tekintettel a munkaköri kockázatok elemzésére. Nemzeti Közszolgálati Egyetem, Közigazgatás-tudományi Doktori Iskola, PhD értekezés

Kőhalmi L. (2015): A korrupció. Pécs: Pécsi Tudományegyetem Állam-és Jogtudományi Kar Gazdasági Büntetőjogi Kutatóintézet, 111.

Malét-Szabó E. (szerk.) Szemelvények a korrupció pszichológiájából, tankönyv, készült a KÖFOP - 2.2.3. - VEKOP - 16 - 00001 azonosító számú, „Kapacitásfejlesztés és szemléletformálás a korrupciós esetek nagyobb arányú felderítése, illetve megelózés érdekében" projekt keretében Malét-Szabó E. (2018/a): ,, A HR lehetöségei a szilárd erkölcsiség szolgálatában”, konferencia előadás, a KÖFOP-2.2.3-VEKOP-16-2016-0001. azonosítószámú, „Kapacitásfejlesztés és szemléletformálás a korrupciós esetek nagyobb arányú felderítése, illetve megelözése érdekében” címü projekt tájékoztató rendezvénye. Belügyminisztérium, 2018. november 14.

Malét-Szabó E. (2018/b): Integritás és szilárd erkölcsiség - szürés vagy képzés a biztonság kulcsa; konferencia előadás; A biztonság sokszínủ arca; innováció - tudomány - információbiztonság közszolgálat; szervezö: Belügyi Tudományos Tanács, 2018. november 7-8. Budapest, Duna Palota

Malét-Szabó E. (2016): A szilárd erkölcsiség mérésének lehetséges helye és szerepe a rendvédelemben. Rendvédelem, 1

Münnich Á. (2018): A SZEM-modell és a SZEM-teszt koncepciója a kutatási eredmények függvényében, a KÖFOP-2.2.3-VEKOP-16-2016-0001. azonosítószámú, „Kapacitásfejlesztés és szemléletformálás a korrupciós esetek nagyobb arányú felderítése, illetve megelőzése érdekében” címü projekt tájékoztató rendezvénye. Belügyminisztérium, 2018. november 14.

Pulay Gy. (2014): A korrupció megelözése a szervezeti integritás megerösitése által, Pénzügyi Szemle, 2, 151-166.
Réthy G. (2016): A korrupció kultúrája A kultúra és korrupció kapcsolatának vizsgálata a legelfogadottabb kultúraösszehasonlitó modellek alkalmazásával, Miskolci Egyetem Vállalkozáselmélet és gyakorlat Doktori Iskola, PhD. értekezés.

Szemán-Nagy A.: Személyiségvonások szerepe a korrupciós cselekedetek létrejöttében = BM SZEM E-learningek. Dr. Maléth-Szabó Erika (szerk.), 4-20. (belső anyag)

Takács I., Csapodi P., Takács-György K. (2011): A korrupció, mint deviáns társadalmi attitüd. Pénzügyi Szemle, 1, 26-42.

Varga Sz. (2017): A korrupció mint destruktív vállalkozás. Doktori (PhD) értekezés, Budapesti Corvinus Egyetem, Szociológia Doktori Iskola

\section{A cikkben szereplő online hivatkozások}

URL1: Báger G., Pulay Gy., Korbuly A. (2008): Korrupciós kockázatok feltérképezése a magyar közszférában, Állami Számvevöszék Fejlesztési Módszertani Intézet. https://asz.hu/storage/files/files/Publikaciok/Egyeb_Publikaciok/2008/t230.pdf?ctid=871

URL2: Nemzeti Korrupcióellenes Program (2016) http://korrupciomegelozes.kormany.hu/download/9/ff/91000/NKP\%20Program.pdf

URL3: Hunyady Gy., Münnich A. (2015): A rendvédelmi szervek személyi állományára vonatkozó szilárd erkölcsiség elvárás pszichológiai szempontú elemzése és modellezése (kivonat). In: Malét-Szabó E. (szerk.): Az erkölcsi értékrend és a személyiség közötti kapcsolat vizsgálati szempontjai, 73-.83. https://bmprojektek.kormany.hu/download/5/0a/51000/Az\%20 erk\%C3\%B6lcsi\%20\%C3\%A9rt\%C3\%A9krend\%20\%C3\%A9s\%20a\%20szem\%C3\%A9lyis\%C3\%A9g\%20k\%C3\%B6z\%C3\%B6tti\%20kapcsolat.pdf

URL4: Pallai K. (2010): Párbeszéd, normák és az argumentativ módszer. Az értékalapú kormányzás cimü tárgyhoz az integritás tanácsadó szakirányú továbbképzés keretében. https:// cmsadmin-pub.uni-nke.hu/document/vtkk-uni-nke-hu/pallai-katalin-jegyzet-parbeszed-normak-es-argumnetativ-eszkozok-1.original.pdf

URL5: SZEMmodell e-learning tananyag elkészitése - eredményröl szóló tájékoztató https:// www.kozbeszerzes.hu/data/hirdetmeny/portal_586121/portal_4795_2018.pdf

URL6: A Bizottság Közleménye az Európai Parlamentnek, a Tanácsnak és a Szociális Bizottságnak: A korrupció elleni uniós küzdelem. https://eur-lex.europa.eu/legal-content/HU/TXT /?uri=celex\%3A52011DC0308

URL7: „,Kapacitásfejlesztés a korrupciós esetek nagyobb arányú felderitése, illetve megelözés érdekében" https://fejlesztesiprogramok.uni-nke.hu/kofop-projektek/kofop-223-vekop-162016-00001/a-projekt-adatai

URL8: Magyary Zoltán Közigazgatás-fejlesztési Program 12.0 (2012) https://magyaryprogram. kormany.hu/admin/download/d/2c/40000/Magyary\%20kozig\%20fejlesztesi\%20program\%20 2012\%20A4.pdf 